\title{
PENGARUH KONFLIK PERAN, KOMITMEN ORGANISASI, PEMAHAMAN GOOD GOVERNANCE DAN BUDAYA ORGANISASI TERHADAP KINERJA PEMERIKSA BPK PERWAKILAN PROVINSI NTT
}

\author{
Rosy Rahayu Nurkasih ${ }^{1)}$ Sulaiman $^{2)}$ Akbar Yusuf ${ }^{2)}$ \\ ${ }^{1)}$ Alumni Program Studi Akuntansi Universitas Muhammadiyah Kupang \\ ${ }^{2)}$ Dosen Tetap Program Studi Akuntansi Universitas Muhammadiyah Kupang
}

\begin{abstract}
ABSTRAK
Penelitian ini bertujuan untuk mengetahui pengaruh konflik peran, komitmen organisasi, pemahaman good governance dan budaya organisasi terhadap kinerja pemeriksa BPK Perwakilan Provinsi NTT. Penelitian ini adalah penelitian kuantitatif dengan sampel yang digunakan adalah populasi/penelitian sensus sebanyak 73 pemeriksa pada Badan Pemeriksa Keuangan Perwakilan Provinsi NTT. Teknik analisis yang digunakan dalam penelitian ini adalah regresi berganda. Variabel independen yang digunakan dalam penelitian ini meliputi konflik peran, komitmen organisasi, pemahaman good governance dan budaya organisasi, serta variabel dependennya adalah kinerja pemeriksa. Hasil penelitian ini menunjukkan bahwa secara parsial konflik peran, komitmen organisasi, dan budaya organisasi berpengaruh signifikan terhadap kinerja pemeriksa. Sedangkan untuk pemahaman good governance secara parsial tidak terbukti berpengaruh signifikan terhadap kinerja pemeriksa. Pengujian secara simultan menunjukkan konflik peran, komitmen organisasi, pemahaman good governance dan budaya organisasi berpengaruh signifikan terhadap kinerja pemeriksa.
\end{abstract}

Kata Kunci : Konflik Peran, Komitmen Organisasi, Pemahaman Good Governance, Budaya Organisasi, Kinerja Pemeriksa.

\section{PENDAHULUAN}

Kinerja suatu organisasi dinilai baik jika organisasi yang bersangkutan mampu melaksanakan tugas-tugas dalam rangka mencapai tujuan yang telah ditetapkan pada standar yang tinggi dengan biaya yang rendah. Konsep ekonomi yang berarti pemerolehan input dengan kualitas dan kuantitas tertentu pada harga terendah, efisiensi yaitu 2 penggunaan input terendah untuk mencapai output tertentu dan efektivitas yaitu perbandingan antara hasil yang diharapkan dengan hasil yang sesungguhnya dicapai (Mardiasmo, 2009). Sektor publik sering dinilai sebagai sarang inefisiensi, pemborosan, sumber kebocoran dana dan institusi yang selalu merugi. Dengan demikian, melalui audit sektor publik dapat dilakukan tindakan pendeteksian dan pencegahan atas berbagai praktik korupsi, penyelewengan, pemborosan dan kesalahan dalam pengelolaan sumber daya publik serta penyelamatan aset-aset negara. Tanpa ada 
lembaga audit sektor publik yang independen, bersih, kompeten, profesional dan berwibawa maka akan rusak dan rapuh tatanan pemerintahan (Mahmudi, 2011).

Konflik peran adalah suatu konflik yang timbul karena mekanisme pengendalian birokrasi organisasi tidak sesuai dengan norma, aturan, etika dan kemandirian profesional. Kondisi tersebut biasanya terjadi karena adanya dua perintah yang berbeda yang diterima secara bersamaan, dan pelaksanaan salah satu perintah saja akan mengakibatkan terabaikannya perintah yang lain (Fanani ddk 2008). Yuskar dan Devisia (2011) menjelaskan komitmen organisasional dibangun atas dasar kepercayaan pekerja atas nilai-nilai organisasi, kerelaan pekerja membantu mewujudkan tujuan organisasi dan loyalitas untuk tetap menjadi anggota organisasi. Pemahaman good governance merupakan wujud penerimaan akan pentingnya suatu perangkat peraturan atau tata kelola yang baik untuk mengatur hubungan, fungsi dan kepentingan berbagai pihak dalam urusan bisnis maupun pelayanan public (Trianingsih, 2007). . Kreitner dan Kinicki dalam Trisnaningsih (2007) mendefinisikan budaya organisasi sebagai perekat perusahaan melalui nilai-nilai yang ditaati, peralatan simbolik dan cita- 8 cita sosial yang ingin dicapai.

Penelitian terdahulu mengenai konflik peran yang dilakukan oleh Fanani,dkk (2008) menyimpulkan konflik peran berpengaruh negatif dan signifikan terhadap kinerja auditor. Begitu pula dengan hasil penelitian Maulana, dkk (2012) yang memberikan kesimpulan konflik peran berpengaruh signifikan terhadap kinerja auditor. Yulistiyani (2014) yang memberikan kesimpulan bahwa komitmen organisasi berpengaruh terhadap 6 kinerja auditor yang bekerja pada Kantor Akuntan Publik di Surakarta dan Yogyakarta. Penelitian tentang pemahaman good governance terhadap kinerja auditor dilakukan oleh Sapariyah (2011) yang menyimpulkan good governance berpengaruh positif dan signifikan terhadap Kinerja Auditor. Penelitian Hanna dan Firnanti (2013) mengindikasikan bahwa auditor dalam kinerjanya dipengaruhi oleh budaya organisasi tempat dia bekerja.

Penelitian ini dimotivasi oleh pentingnya kinerja pemeriksa dalam menentukan kinerja BPK yang berkualitas. Pemeriksa harus dapat mengendalikan dirinya dalam memandang suatu peristiwa dan mampu menghadapi berbagai tantangan dan ancaman agar lebih bisa menjaga etika profesionalisme. Penelitian ini merupakan penelitian replikasi di mana variabel-variabel yang digunakan telah diuji dalam penelitian 
sebelumnya namun perbedaan penelitian ini terletak pada tempat penelitian yaitu pada BPK Perwakilan Provinsi NTT, sehingga peneliti tertarik untuk judul ini sebagai penelitian penulis yaitu pengaruh konflik peran, komitmen organisasi, pemahaman good governance dan budaya organisasi terhadap kinerja pemeriksa BPK Perwakilan Provinsi NTT.

Berdasarkan latar belakang diatas tujuan dalam penelitian ini adalah a) untuk mengetahui pengaruh konflik peran terhadap kinerja pemeriksa. b) untuk mengetahui pengaruh komitmen organisasi terhadap kinerja pemeriksa. c) untuk mengetahui pengaruh pemahaman good governance terhadap kinerja pemeriksa. d) Untuk mengetahui pengaruh budaya organisasi terhadap kinerja pemeriksa. e. Untuk mengetahui pengaruh konflik peran, komitmen organisasi, pemahaman good governance dan budaya organisasi secara simultan terhadap kinerja pemeriksa.

\section{TINJAUAN PUSTAKA}

\section{Teori Sikap dan Perilaku}

Teori sikap dan perilaku dikembangkan oleh Triandis dalam Sumirat (2006), menyatakan bahwa perilaku ditentukan oleh sikap, aturan-aturan sosial dan kebiasaan. Sikap terdiri dari komponen kognitif yaitu keyakinan, komponen afektif yaitu suka atau tidak suka, berkaitan dengan apa yang dirasakan dan komponen perilaku yaitu bagaimana seorang ingin berperilaku terhadap sikap. Sikap menurut Fishbein dan Jazen dalam Sumirat (2006) menyatakan 1) sikap dapat dipelajari, 2) sikap mendefinisikan prediposisi kita terhadap aspekaspek yang terjadi di dunia, 3) sikap memberikan dasar perasaan bagi hubungan antara pribadi kita dengan orang lain, 4) sikap diatur dan dekat dengan inti kepribadian

\section{Teori Peran}

Menurut Khan dalam Agustina (2009) teori peran merupakan penekanan sifat individual sebagai perilaku sosial yang mempelajari perilaku yang sesuai dengan posisi yang ditempati di masyarakat. Peran adalah konsep sentral dari teori peran (Shaw \& Constanzo dalam Agustina, 2009). Dengan demikian kajian mengenai teori peran tidak lepas dari definisi peran dan berbagai istilah perilaku di dalamnya. Peran mencerminkan posisi seseorang dalam sistem sosial dengan hak kewajiban, kekuasaan dan tanggung jawab yang menyertainya. Untuk dapat berinteraksi satu sama lain, orang-orang 
memerlukan cara tertentu guna mengantisipasi perilaku orang lain. Peran melakukan fungsi ini dengan sistem sosial. Seseorang memiliki peran, baik dalam pekerjaan maupun di luar itu. Masing-masing peran menghendaki perilaku yang berbeda-beda. Dalam lingkungan pekerjaan itu sendiri seorang karyawan mungkin lebih dari satu peran,seorang karyawan bisa berperan sebagai bawahan, anggota serikat pekerja, dan wakil dalam panitia keselamatan kerja

\section{Kinerja Pemeriksa}

Kinerja Auditor merupakan gambaran mengenai tingkat pencapaian pelaksanaan suatu kegiatan program/kebijakan dalam mewujudkan sasaran, tujuan, misi dan visi organisasi yang tertuang dalam strategic planning suatu organisasi (Mahsun dalam Wati, dkk 2010). Pengertian kinerja auditor menurut Fanani, dkk (2008) adalah perwujudan kerja yang dilakukan dalam rangka mencapai hasil kerja yang lebih baik atau lebih menonjol kearah tercapainya tujuan organisasi. Arfan dalam Ikhlas (2014) mengemukakan bahwa kinerja auditor merupakan hasil evaluasi terhadap pekerjaan auditor dalam melaksanakan pemeriksaan yang diukur berdasarkan standar audit yang berlaku.

Pengertian kinerja auditor menurut Mulyadi dalam Trisnaningsih (2007) adalah akuntan publik yang melaksanakan penugasan pemeriksaan (examination) secara obyektif atas laporan keuangan suatu perusahaan atau organisasi lain dengan tujuan untuk menentukan apakah laporan keuangan tersebut menyajikan secara wajar sesuai dengan prinsip akuntansi yang berlaku umum, dalam semua hal yang material, posisi keuangan dan hasil usaha perusahaan. Kalbers dan Forgarty dalam Trisnaningsih (2007) mengemukakan bahwa kinerja auditor sebagai evaluasi terhadap pekerjaan yang dilakukan oleh atasan, rekan kerja, diri sendiri, dan bawahan langsung.

\section{Konflik Peran}

Konflik peran adalah suatu gejala psikologis yang dialami oleh anggota organisasi yang bisa menimbulkan rasa tidak nyaman dalam bekerja dan secara potensial bisa menurunkan motivasi kerja, sehingga bisa menurunkan kinerja secara keseluruhan (Tsai dan Shis, dalam Fanani, dkk 2008). Terdapat dua macam konflik peran, yaitu konflik antara berbagai peran yang berbeda, dan konflik dalam satu peran tunggal. Satu atau lebih peran mungkin menimbulkan kewajiban-kewajiban yang bertentangan bagi seseorang. Dalam peran tunggal mungkin ada konflik inheren. 
Adanya harapan-harapan yang bertentangan dalam satu peran yang sama dinamakan role strain. Konflik peran ini timbul karena mekanisme pengendalian birokrasi organisasi tidak sesuai dengan norma, aturan, etika, dan kemandirian profesional. Kondisi ini umumnya terjadi karena adanya beberapa perintah yang berbeda yang diterima secara bersamaan, dan pelaksanaan atas salah satu perintah saja akan mengakibatkan terabaikannya perintah yang lain

\section{Komitmen Organisasi}

Komitmen organisasi merupakan sikap yang menunjukkan "loyalitas" karyawan dan merupakan proses berkelanjutan bagaimana seorang anggota organisasi mengekspresikan perhatian mereka kepada kesuksesan dan kebaikan organisasinya (Luthans dalam Hanna dan Firnanti, 2013).

Robbins dalam Sumirat (2006) mengemukakan komitmen organisasi merupakan salah satu sikap yang merefleksikan perasaan suka atau tidak suka terhadap organisasi tempat bekerja. Selanjutnya, Meyer dan Allen dalam Sumirat (2006) mengemukakan tiga komponen tentang komitmen organisasi: 1) Affective Commitment, terjadi apabila karyawan ingin menjadi bagian dari organisasi karena adanya ikatan emosional (emotional attachment) atau merasa mempunyai nilai sama dengan organisasi, 2) Continuance Commitment, yaitu kemauan individu untuk tetap bertahan dalam organisasi karena tidak menemukan pekerjaan lain atau karena rewards ekonomi tertentu, 3) Normative Commitment, timbul dari nilai-nilai karyawan. Karyawan bertahan menjadi anggota organisasi karena ada kesadaran bahwa berkomitmen terhadap organisasi merupakan hal yang memang seharusnya dilakukan.

\section{Pemahaman Good Governance}

Good governance merupakan tata kelola yang baik pada suatu usaha yang dilandasi oleh etika profesional dalam berusaha/berkarya. Pemahaman good governance merupakan wujud penerimaan akan pentingnya suatu perangkat peraturan atau tata kelola yang baik untuk mengatur hubungan, fungsi dan kepentingan berbagai pihak dalam urusan bisnis maupun pelayanan publik. Pemahaman atas good governance adalah untuk menciptakan keunggulan manajemen kinerja baik pada perusahaan bisnis manufaktur (good corporate governance) ataupun perusahaan jasa, serta lembaga pelayanan publik/pemerintahan (good government governance). Pemahaman good governance merupakan wujud respek terhadap sistem dan struktur yang baik untuk 
mengelola perusahaan dengan tujuan meningkatkan produktivitas usaha. Munculnya konsep good governance di Indonesia sebagai reaksi atas perilaku pengelola perusahaan yang tidak memperhitungkan stakeholder-nya. Hal ini terlihat jelas ketika krisis terjadi di Indonesia sejak pertengahan tahun 1997. Krisis tersebut memberi pelajaran berharga bahwa pembangunan yang dilaksanakan selama ini ternyata tidak didukung struktur ekonomi yang kokoh. Hampir semua pengusaha besar kita menjalankan roda bisnis dengan manajemen yang tidak baik dan sarat praktek korupsi, kolusi dan nepotisme (Trisnaningsih, 2007).

Aturan organisasi merupakan salah satu faktor penting yang mempengaruhi kinerja auditor dalam menjalankan profesi, karena pemahaman auditor tentang konsep yang baik diharapkan memberikan hasil kerja yang baik (Ikhlas, 2014). Dengan melaksanakan good governance dapat menciptakan proses pengambilan keputusan yang lebih baik, meningkatkan efisiensi operasional perusahaan serta lebih meningkatkan pelayanan kepada stakeholders (Yuskar dan Devisia, 2011).

\section{Budaya Organisasi}

Budaya merupakan satu titik pandang yang pada saat bersamaan dijadikan jalan hidup oleh suatu masyarakat. Tidak terdapat masyarakat tanpa suatu budaya, dan budaya tidak ada di luar suatu masyarakat. Jika demikian, maka budaya atau jalan hidup meliputi sistem kepercayaan umum yang sesuai dengan harapan gaya perilaku atau pemikiran dan pengetahuan teknis, serta menentukan cara melakukan sesuatu. Budaya mempengaruhi pola teladan perilaku manusia yang teratur karena budaya menggambarkan perilaku yang sesuai untuk situasi tertentu. Aspek budaya yang terpenting adalah memastikan kehidupan manusia baik secara fisik maupun secara sosial. Dengan demikian, seorang akuntan perilaku harus menyadari akan gagasan untuk budaya (Ikhsan dan Ishak dalam Ikhlas 2014)

\section{Kerangka Konsep dan Pengembangan Hipotesis}

\section{a) Hubungan Konflik Peran dengan Kinerja Pemeriksa}

Konflik peran adalah suatu konflik yang timbul karena mekanisme pengendalian birokrasi organisasi tidak sesuai dengan norma, aturan, etika dan kemandirian profesional. Kondisi tersebut biasanya terjadi karena adanya dua perintah yang berbeda yang diterima secara bersamaan, dan pelaksanaan salah satu perintah saja akan 
mengakibatkan terabaikannya perintah yang lain (Fanani, dkk 2008).Penelitian mengenai konflik peran dilakukan oleh Ulum dan Purnamasari (2015), penelitian tersebut menyimpulkan konflik peran berpengaruh negatif terhadap kinerja auditor, semakin tinggi konflik peran maka kinerja auditor akan semakin rendah. Penelitian Fanani, dkk (2008) juga menyimpulkan konflik peran berpengaruh negatif dan signifikan terhadap kinerja auditor.

Berdasarkan definisi dan penelitian terdahulu diatas maka hipotesis pada penelitian ini adalah

$H_{1}:$ Konflik peran berpengaruh terhadap kinerja pemeriksa

\section{b) Hubungan Komitmen Organisasi denagan Kinerja Pemeriksa}

Komitmen merupakan suatu konsistensi dari wujud keterikatan seseorang terhadap suatu hal. Adanya suatu komitmen dapat menjadi suatu dorongan bagi seseorang untuk bekerja lebih baik (Wati, dkk 2010). Penelitian tentang komitmen organisasi dilakukan oleh Wati, dkk (2010) yang menyimpulkan bahwa komitmen organisasi bepengaruh positif terhadap kinerja auditor pemerintah. Kemudian penelitian Trisnaningsih (2007) juga menyimpulkan komitmen organisasi berpengaruh signifikan terhadap kinerja auditor terbukti atau didukung dengan fakta.

Berdasarkan penelitian difinisi dan penelitian terdahulu diatas maka hipotesis dalam penelitian ini adalah

$\mathrm{H}_{2}$ : Komitmen organisasi berpengaruh terhadap kinerja pemeriksa

\section{c) Hubungan Pemahaman Good Governance dengan Kinerja Pemeriksa}

Good governance merupakan tata kelola yang baik pada suatu usaha yang dilandasi oleh etika profesional dalam berusaha/berkarya. Pemahaman atas good governance untuk menciptakan keunggulan manajemen kinerja baik pada perusahaan bisnis manufaktur (good corporate governance) ataupun perusahaan jasa, serta lembaga pelayanan publik/pemerintahan (good government governance). Penelitian tentang pemahaman good governance terhadap kinerja auditor dilakukan oleh Sapariyah (2011) dan Wati, dkk (2010) yang sama-sama menyimpulkan good governance berpengaruh positif dan signifikan terhadap kinerja auditor. 
Berdasarkan penelitian difinisi dan penelitian terdahulu diatas maka hipotesis dalam penelitian ini adalah

$H_{3}$ : Pemahaman good governance berpengaruh terhadap kinerja pemeriksa

\section{d) Hubungan Budaya Organisasi dengan Kinerja Pemeriksa}

Budaya organisasi merupakan pola pemikiran, perasaan dan tindakan dari suatu kelompok sosial yang membedakan dengan kelompok sosial yang lain. Budaya organisasi juga merupakan salah satu variabel penting bagi seorang pemimpin, karena budaya organisasi mencerminkan nilai-nilai yang diakui dan menjadi pedoman bagi pelaku anggota organisasi (Yuskar dan Devisia, 2011). Penelitian mengenai budaya organisasi dengan kinerja auditor telah dilakukan oleh Yuskar dan Devisia (2011) yang menyimpulkan budaya organisasi berpengaruh terhadap kinerja auditor, semakin baik dan tinggi nilai budaya organisasi tempat ia melaksanakan tugas profesinya, maka semakin baik dan tinggi pula kinerja yang dapat dicapai oleh seorang auditor.

Berdasarkan penelitian difinisi dan penelitian terdahulu diatas maka hipotesis dalam penelitian ini adalah

H4 : Budaya Organisasi berpengaruh terhadap kinerja pemeriksa

\section{METODE PENELITIAN}

\section{Desain Penelitian}

Desain penelitian yang digunakan untuk menganalisis penelitian ini yaitu dengan pendekatan explanatory research, karena penelitian ini bermaksud untuk menjelaskan hubungan kausal antara variabel-variabel dengan melalui pengujian hipotesis yang telah dirumuskan. Sedangkan pendekatan penelitan ini menggunakan cross sectional yaitu penelitian yang dilakukan satu waktu dan satu kali

\section{Populasi dan Sampel}

Sumber data dalam penelitian adalah subjek dari mana data dapat diperoleh (Arikunto, 2010). Populasi adalah keseluruhan subjek penelitian (Arikunto, 2010). Populasi dalam penelitian ini adalah seluruh pemeriksa pada BPK Perwakilan Provinsi NTT yang berjumlah 73 orang tanpa membedakan jenis kelamin, pendidikan dan pengalaman kerja. Karena jumlah populasi kurang dari 100 responden, maka metode 
pemilihan sampel yang digunakan adalah metode sensus, yaitu penyebaran kuesioner dilakukan pada semua populasi (Efendy, 2010).

\section{Definisi Operasional dan Indikator}

\section{Kinerja pemeriksaan}

Kinerja auditor merupakan suatu hasil kerja yang dicapai seorang auditor yang melakukan pekerjaannya dalam pemeriksaan laporan keuangan dan menjadi suatu pengukuran apakah hasil kerja seorang auditor tersebut sudah baik ataupun buruk (Hanna dan Firnanti, 2013).Variabel kinerja pemeriksa dalam penelitian ini diukur menggunakan instrumen yang dikembangkan oleh Larkin yang direplikasikan oleh Trisnaningsih (2007) dengan jumlah sebanyak dua belas butir pertanyaan yaitu antara lain kemampuan, komitmen profesi, motivasi, dan kepuasan kerja.

\section{Konflik Peran}

Menurut Hanna dan Firnanti (2013), konflik peran merupakan suatu bentuk ketidaknyamanan anggota organisasi dalam melakukan pekerjaannya yang bermula dari munculnya dua perintah yang diterima secara bersamaan yang memiliki akibat pada menurunkan motivasi kerja. Variabel konflik peran dalam penelitian ini diukur dengan menggunakan instrumen yang dikembangkan oleh Rizzo, dkk dalam Fanani, dkk (2008) dengan jumlah tujuh butir pertanyaan.

\section{Komitmen Organisasi}

Variabel komitmen organisasi diukur dengan menggunakan instrumen yang dikembangkan oleh Meyer dan Allen, telah direplikasi oleh Trisnaningsih (2007). Instrumen terdiri dari 7 item komitmen organisasi affective (berhubungan dengan satu pandangan profesionalisme yaitu pengabdian pada profesi) dan 5 item komitmen continuance (berhubungan secara positif dengan pengalaman dan secara negatif dengan pandangan profesionalisme kewajiban sosial).

\section{Pemahaman Good governance}

Instrumen pemahaman atas good governance diukur dengan menggunakan instrumen yang dikembangkan oleh Indonesian Institute of Corporate Governance yang telah direplikasikan oleh Trisnaningsih (2007) dengan jumlah sebanyak delapan butir pertanyaan. Instrumen tersebut diukur dengan empat indikator variabel yaitu: prinsip keadilan, transparansi, akuntabilitas, dan pertanggungjawaban

\section{Budaya Organisasi}


Variabel budaya organisasi dalam penelitian ini diukur dengan menggunakan instrumen yang dikembangkan oleh Hofstede yang telah direplikasikan oleh Trisnaningsih (2007) dengan jumlah sebanyak delapan butir pertanyaan. Instrumen terdiri dari 4 elemen budaya organisasi yang berorientasi pada orang dan 4 elemen budaya organisasi yang berorientasi pada pekerjaan.

\section{Tehnik analisa data}

Teknik analisa yang digunakan dalam penelitian ini terdiri dari Statistik Deskriptif,, Pengujian Instrumen (uji validitas dan uji reabilitas, Uji asumsi klasik).

\section{Uji Regresi}

Pengujian hipotesis 1, 2, 3, 4 dan 5 menggunakan analisis regresi berganda. Penggunaan model regresi berganda dimaksudkan untuk mengetahui secara parsial dan simultan pengaruh variabel independen yang terdiri dari konflik peran (X1), komitmen organisasi (X2), pemahaman good governance (X3) dan budaya organisasi (X4) terhadap variabel dependen yaitu kinerja pemeriksa (Y).

Sesuai dengan Gujarati dalam Ghozali (2013) maka secara umum formulasi persamaan dari regresi berganda dapat ditulis sebagai berikut :

$$
\begin{aligned}
& \mathbf{Y}=\mathbf{a}+\mathbf{b} 1 \mathbf{K p X} 1+\mathbf{b} \mathbf{K} \mathbf{K X} \mathbf{2}+\mathbf{b 3 P g g X 3}+\mathbf{b 4 B o X} 4+\mathbf{e} \\
& \text { Keterangan: } \\
& \mathrm{Y}=\text { Kinerja Pemeriksa } \\
& \mathrm{a}=\text { Nilai intercept/constant } \\
& \mathrm{b}=\text { Koefisien regresi } \\
& \mathrm{X} 1=\text { Konflik peran } \\
& \mathrm{X} 2=\text { Komitmen organisasi } \\
& \mathrm{X} 3=\text { Pemahaman good governance } \\
& \mathrm{X} 4=\text { Budaya organisasi } \\
& \mathrm{e}=\text { error }
\end{aligned}
$$

\section{HASIL PENELITIAN DAN PEMBAHASAN}

Statistik deskriptif

\begin{tabular}{|l|l|l|l|l|l|}
\hline & N & Maximum & Minimum & Mean & $\begin{array}{l}\text { Std } \\
\text { Deviasi }\end{array}$ \\
\hline Kinerja Pemeriksa & 65 & 25,00 & 54,00 & 39,5538 & 4,93087 \\
\hline Konflik Peran & 65 & 11,00 & 34,00 & 21,8462 & 4,26553 \\
\hline Komitmen Organisasi Good & 65 & 27,00 & 57,00 & 42,4923 & 6,55534 \\
\hline $\begin{array}{l}\text { Pemahaman } \\
\text { Governance }\end{array}$ & 65 & 29,00 & 40,00 & 34,1077 & 3,12311 \\
\hline Budaya Organisasi & 65 & 16,00 & 34,00 & 24,6000 & 4,11096 \\
\hline
\end{tabular}




\section{Uji validitas}

Dari hasil uji validitas keseluruhan pernyataan memiliki nilai korelasi dengan signifikansi yang lebih kecil dari parameter $(\alpha)$ yang digunakan yaitu 0,05 , sehingga dapat disimpulkan bahwa semua item indikator instrumen mengenai kinerja pemeriksa (Y), konflik peran (X1), komitmen organisasi (X2), pemahaman good governance (X3) dan budaya organisasi (X4) tersebut valid.

\section{Uji reliabilitas}

Dari hasil uji reliabilitas keseluruhan instrumen variabel memiliki nilai koefisien alpha lebih besar dari 0,70, sehingga dapat disimpulkan bahwa instrumen mengenai kinerja pemeriksa (Y), konflik peran (X1), komitmen organisasi (X2), pemahaman good governance (X3) dan budaya organisasi (X4) tersebut reliabel.

\section{Uji asumsi klasik}

Hasil ketiga uji asumsi klasik yaitu uji normalitas, uji multikolinieritas dan uji heteroskedastisitas maka disimpulkan bahwa model regresi dapat digunakan untuk menguji hipotesis.

\section{PEMBAHASAN}

\section{1) Hubungan Konflik Peran dengan Kinerja Pemeriksa}

Berdasarkan hasil pengujian menunjukkan bahwa konflik peran berpengaruh terhadap kinerja pemeriksa. Koefisien regresi variabel konflik peran (X1) sebesar -0,297 menjelaskan bahwa konflik peran berpengaruh negatif terhadap kinerja pemeriksa. Jadi semakin tinggi konflik peran maka kinerja pemeriksa akan semakin rendah. Hasil penelitian ini mendukung penelitian Fanani dkk. (2008) dan Ulum dan Purnamasari (2015). Sedangkan hasil penelitian Hanna dan Firnanti (2013) dan Kristina (2014) yang menyatakan konflik peran tidak berpengaruh terhadap kinerja pemeriksa, tidak sesuai dengan hasil penelitian ini. Hasil penelitian ini membuktikan bahwa konflik peran merupakan faktor yang penting dalam kinerja pemeriksa. Semakin tinggi konflik peran maka kinerja auditor akan semakin rendah. Pekerjaan yang berbeda dalam satu waktu membuat auditor mengalami konflik peran dan mengalami tekanan dan stress dalam bekerja. Hal ini membuat seorang auditor akan mengalami penurunan kinerja (Ulum dan Purnamasari, 2015). 


\section{2) Hubungan Komitmen Organisasi dengan Kinerja Pemeriksa}

Berdasarkan hasil pengujian menunjukkan bahwa komitmen organisasi berpengaruh terhadap kinerja pemeriksa. Koefisien regresi variable komitmen organisasi (X2) sebesar 0,209 menjelaskan bahwa komitmen organisasi berpengaruh positif terhadap kinerja pemeriksa. Jadi semakin tinggi komitmen seorang pemeriksa terhadap organisasi akan meningkatkan kinerja pemeriksa. Hasil penelitian ini mendukung penelitian Trisnaningsih (2007) dan Wati,dkk (2010). Sedangkan hasil penelitian Siahaan (2010) yang menyatakan komitmen organisasi tidak berpengaruh terhadap kinerja pemeriksa, tidak sesuai dengan hasil penelitian ini. Hasil penelitian ini membuktikan bahwa komitmen organisasi merupakan faktor yang penting dalam kinerja pemeriksa. Seorang auditor yang memiliki komitmen yang tinggi terhadap organisasi di mana dia bekerja maka akan timbul rasa memiliki terhadap organisasi, dia akan merasa senang dalam bekerja dan dia akan bekerja sebaik mungkin untuk organisasinya tersebut sehingga kinerjanya akan meningkat (Wati, dkk. 2010).

\section{3) Hubungan Pemahaman Good Governance dengan Kinerja Pemeriksa}

Berdasarkan hasil pengujian menunjukkan bahwa pemahaman good governance tidak berpengaruh terhadap kinerja pemeriksa. Koefisien regresi variabel pemahaman good governance (X3) sebesar 0,044 menjelaskan bahwa pemahaman good governance tidak berpengaruh terhadap kinerja pemeriksa. Hasil penelitian ini mendukung penelitian Trisnaningsih (2007) dan Ikhlas (2014). Sedangkan hasil penelitian Wati,dkk (2010) yang menyatakan pemahaman good governance berpengaruh terhadap kinerja pemeriksa, tidak sesuai dengan hasil penelitian ini. Hasil penelitian ini membuktikan pula apa yang dikemukakan Yuskar dan Devisia (2011) bahwa seorang auditor yang hanya memahami good governance tetapi dalam tahapan auditnya tidak menegakkan independensinya maka tidak akan berpengaruh terhadap kinerjanya. Secara implisit pemahaman good governance dapat meningkatkan kinerja auditor jika auditor tersebut selama tahapan audit menegakkan independensi auditor. Hal tersebut dapat dipahami bahwa pemahaman good governance memang memegang peranan penting dalam tata kelola organisasi dan individu, namun kinerja pemeriksa tidak sebatas dipengaruhi oleh pemahamannya saja tanpa dipengaruhi oleh faktor lain yang mempengaruhi secara langsung kinerja seorang pemeriksa. 


\section{4) Hubungan Budaya Organisasi dengan Kinerja Pemeriksa}

Berdasarkan hasil pengujian menunjukkan bahwa budaya organisasi berpengaruh terhadap kinerja pemeriksa. Koefisien regresi variabel budaya organisasi (X4) sebesar 0,456 menjelaskan bahwa budaya organisasi berpengaruh positif terhadap kinerja pemeriksa. Hasil penelitian menunjukkan bahwa budaya organisasi berpengaruh terhadap kinerja pemeriksa. Jadi semakin baik budaya yang dimiliki oleh sebuah organisasi akan meningkatkan kinerja pemeriksa. Hasil penelitian ini mendukung penelitian Hanna dan Firnanti (2013) dan Ikhlas (2014). Sedangkan hasil penelitian Trisnaningsih (2007) dan Yuskar dan Devisia (2011) yang menyatakan budaya organisasi tidak berpengaruh terhadap kinerja pemeriksa, tidak sesuai dengan hasil penelitian ini. Hasil penelitian ini membuktikan bahwa budaya organisasi adalah suatu sistem nilai yang dirasakan maknanya oleh seluruh orang dalam perusahaan. Selain dipahami, seluruh jajaran menyakini sistem nilai tersebut sebagai landasan gerak perusahaan (Siagian dalam Trisnaningsih, 2007). Budaya organisasi yang kuat diperlukan oleh setiap organisasi agar kepuasan kerja dan kinerja karyawan meningkat, sehingga akan meningkatkan kinerja organisasi secara keseluruhan (Murtanto dan Djasmin dalam Hanna dan Firnanti, 2013)

\section{5) Hubungan Konflik Peran, Komitmen Organisasi, Pemahaman Good Governance dan Budaya Organisasi dengan Kinerja Pemeriksa secara Simultan}

Berdasarkan hasil pengujian menunjukkan bahwa konflik peran, komitmen organisasi, pemahaman good governance dan budaya organisasi berpengaruh secara simultan terhadap kinerja pemeriksa. Koefisien regresi variabel konflik peran, komitmen organisasi, pemahaman good governance dan budaya organisasi (X5) sebesar 0,329 menjelaskan bahwa konflik peran, komitmen organisasi, pemahaman good governance dan budaya organisasi berpengaruh terhadap kinerja pemeriksa dapat diterima. Penelitian ini membuktikan bahwa konflik peran, komitmen organisasi, pemahaman good governance dan budaya organisasi merupakan faktor-faktor yang mempengaruhi kinerja pemeriksa sehingga seorang pemeriksa secara kolektif harus terhindar dari konflik peran, memiliki komitmen organisasi dan pemahaman good 
governance yang memadai serta budaya organisasi yang baik dalam melaksanakan tugas pemeriksaan untuk mendapatkan kinerja pemeriksa yang baik

\section{KESIMPULAN}

Penelitian ini bertujuan untuk mengetahui pengaruh konflik peran, komitmen organisasi, pemahaman good governance dan budaya organisasi terhadap kinerja pemeriksa. Berdasarkan hasil analisis data, dapat disimpulkan sebagai berikut:

1) Konflik peran berpengaruh signifikan terhadap kinerja pemeriksa. Konflik peran yang baik adalah konflik peran yang sudah seharusnya tidak dimiliki oleh seorang pemeriksa BPK Perwakilan Provinsi NTT sehingga dapat memberikan rasa nyaman dan dapat meningkatkan kinerja pemeriksa.

2) Komitmen organisasi berpengaruh signifikan terhadap kinerja pemeriksa. Hal ini berarti semakin baik komitmen organisasi yang dimiliki oleh seorang pemeriksa akan menunjukkan sikap dan perilaku yang positif terhadap lembaganya dan meningkatkan kinerjanya untuk mewujudkan tujuan organisasi.

3) Pemahaman good governance tidak berpengaruh signifikan terhadap kinerja pemeriksa. Dalam hal ini, pemahaman good governance memang penting bagi pemeriksa BPK namun tidak secara langsung mempengaruhi kinerja pemeriksa dikarenakan pemeriksa BPK lebih mengedepankan nilai profesionalisme sesuai dengan nilai-nilai dasar BPK dalam menjalankan tugas pemeriksaan.

4) Budaya organisasi berpengaruh signifikan terhadap kinerja pemeriksa. Hal ini berarti semakin baik budaya organisasi yang diciptakan oleh sebuah institusi akan memberikan peningkatan terhadap kinerja pemeriksa..

5) Konflik peran, komitmen organisasi, pemahaman good governance dan budaya organisasi berpengaruh signifikan secara simultan terhadap kinerja pemeriksa. Hal ini berarti keempat variabel independen tersebut merupakan faktor-faktor yang mempengaruhi kinerja pemerika.

\section{DAFTAR PUSTAKA}

Agustina, Lidya. 2009. Pengaruh Konflik Peran, Ketidakjelasan Peran dan Kelebihan Peran terhadap Kepuasan Kerja dan Kinerja Auditor (Penelitian pada Kantor Akuntan Publik yang Bermitra dengan Kantor Akuntan Publik Big Four di Wilayah DKI Jakarta). Jurnal Akuntansi Vol.1 No.1. 
Arikunto, Suharsimi. 2010. Prosedur Penelitian - Suatu Pendekatan Praktik. Penerbit Rineka Cipta. Jakarta.

Fanani, Zaenal. dkk. 2008. Pengaruh Struktur Audit, Konflik Peran dan Ketidakjelasan Peran terhadap Kinerja Auditor. Jurnal Akuntansi dan Keuangan Indonesia, Desember Vol.5, No.2.

Ghozali, Imam. 2013. Aplikasi Analisis Multivariat dengan Program SPSS 21. Badan Penerbit Universitas Diponegoro. Semarang.

Hanna, Elizabeth dan Firnanti, Friska. 2013. Faktor-Faktor yang Mempengaruhi Kinerja Auditor. Jurnal Bisnis dan Akuntansi Vol.15 No.1.

Ikhlas, Andi. 2014. Independensi Auditor dan Komitmen Organisasi sebagai Mediasi Pengaruh Pemahaman Good Governance, Gaya Kepemimpinan dan Budaya Organisasi terhadap Kinerja Auditor. Skripsi. Universitas Hasanudin.

Kristina. 2014. Pengaruh Struktur Audit, Konflik Peran, Ketidakjelasan Peran dan Gaya Kepemimpinan terhadap Kinerja Auditor. Skripsi. Universitas Muhammadiyah Surakarta.

Mahmudi. 2011. Akuntansi Sektor Publik. Penerbit UII Press. Yogyakarta.

Mardiasmo. 2009. Akuntansi Sektor Publik. Penerbit Andi. Yogyakarta.

Maulana, Ichwan. dkk. 2012. Pengaruh Struktur Audit, Konflik Peran, Ketidakjelasan Peran, dan Locus of Control terhadap Kinerja Auditor (Studi Empiris di Kantor Akuntan Publik Pekanbaru dan Batam). Jurnal Akuntansi. Universitas Riau.

Sapariyah, Rina Ani. 2011. Pengaruh Good Governance dan Independensi Auditor terhadap Kinerja Auditor dan Komitmen Organisasi. STIE AUB Surakarta

Siahaan, Victor D. 2010. Pengaruh Profesionalisme terhadap Komitmen Organisasi dalam Upaya Meningkatkan Kinerja Auditor (Studi pada Kantor Perwakilan BPK-RI Provinsi Aceh). Jurnal Telaah dan Riset Akuntansi vol.3 No.1.

Sumirat, Gunawan Cahya. 2006. Pengaruh Profesionalisme dan Komitmen Organisasi terhadap Kinerja Internal Auditor dengan Kepuasan Kerja sebagai Variabel Intervening (Studi Empiris pada Internal Auditor PT. Bank ABC). Tesis. Universitas Diponegoro. 
Trisnaningsih, Sri. 2007. Independensi auditor dan komitmen organisasi sebagai mediasi pengaruh pemahaman good governance, gaya kepemimpinan dan budaya organisasi terhadap kinerja auditor. Simposium Nasional Akuntansi X. Makassar.

Ulum, Roudhotul dan Purnamasari, Pupung. 2015. Pengaruh Gaya Kepemimpinan, Konflik Peran, Kelebihan Peran terhadap Kinerja Auditor dengan Kecerdasan Spiritual sebagai Variabel Pemoderasi. Simposium Nasional Akuntansi XVIII. Medan.

Wati, Elya. dkk. 2010. Pengaruh Independensi, Gaya Kepemimpinan, Komitmen Organisasi dan Pemahaman Good Governance terhadap Kinerja Auditor Pemerintah. Simposium Nasional Akuntansi XIII. Purwokerto

Yuskar, dan Devisia, Selly. 2011. Pengaruh Independensi Auditor, Komitmen Organisasi, Pemahaman Good Governance, Integritas Auditor, Budaya Organisasi, dan Etos Kerja terhadap Kinerja Auditor (Studi Empiris pada Kantor Akuntan Publik Big Four yang Berafiliasi di Indonesia Tahun 2011). Simposium Nasional Akuntansi XIV. Aceh 